\title{
Viden, værdi og omstridt ekspertise: Analyse af den danske debat om lægemiddelprioritering
}

Sarah Wadmann, ph.d., cand.scient.san.publ., forsker ved KORA, Det Nationale Institut for Kommuners og Regioners Analyse og Forskning

Behandlingsomkostninger har ikke tidligere måttet informere beslutninger om til- og fravalg af medicinske behandlinger på danske hospitaler. En prioriteringsmodel for sygehusmedicin, som Danske Regioner lancerede i foråret 2016, har gjort op med dette princip. Denne artikel analyserer debatten om prioriteringsmodellen og viser, hvordan den skaber en situation, hvor det nye Medicinråd skal evaluere behandlingsomkostningerne - men uden at kunne gøre brug af gængse sundhedsøkonomiske metoder til at sammenholde effekter og omkostninger.

Introduktion

I takt med spredning af ambitioner om evidensbaseret politik (evidence-based policy) er der fulgt en debat om, i hvilken udstrækning politikere bør basere sig på videnskabelige analyser i beslutningsprocesser, hvilken rolle fakta spiller i demokratisk debat, og hvad der udgør relevante beslutningsgrundlag (Greenhalgh \& Russell 2009). Denne artikel analyserer et igangværende forsøg på at introducere sundhedsøkonomisk evaluering i vurderingen af sygehusmedicin i Danmark. Som reaktion på stigende udgifter til sygehusmedicin har man i flere europæiske lande indført krav om sundhedsøkonomisk evaluering af nye lægemidler (Drummond et al. 2011). I blandt andet England, Norge og Sverige informerer omkostningseffektivitetsanalyser beslutninger om, hvilke lægemidler der skal finansieres inden for de offentlige sundhedsbudgetter (Højgaard et al. 2016). I Danmark har behandlingsomkostninger hidtil ikke måttet indgå i anbefalinger om ibrugtagning af ny sygehusmedicin (Pedersen 2015). Det markerede derfor et nybrud, da Danske Regioner i foråret 2016 lancerede en prioriteringsmodel, som lagde op til, at 
analyse af behandlingsomkostninger skal informere beslutninger om, hvilken medicin det offentlige sygehusvæsen skal tilbyde.

Regionernes udspil blev genstand for betydelig debat, og prioriteringsmodellen blev justeret efter kritik fra centrale aktører. Det kunne i den sammenhæng undre, at Danske Regioner ikke tog afsæt i prioriteringsmodeller, som er udviklet i Norge og Sverige, eftersom der tilsyneladende er opnået positive erfaringer med modellerne i disse lande, og der er væsentlige lighedspunkter med det danske sundhedsvæsen (Højgaard et al. 2016). I stedet blev tyske erfaringer et referencepunkt for, hvad regionernes formandskab omtalte som en "dansk model" tilpasset de "unikke" danske forhold (Hansen \& Stenbæk 2016). Dette til trods for at man i Tyskland ikke inddrager behandlingsomkostningerne i kategoriseringen af lægemidlers merværdi (Højgaard et al. 2016). Spørgsmålet er, hvad der er på spil for aktørerne i debatten om prioriteringsmodellen, og hvordan det har påvirket de politiske løsninger. For at søge svar herpå er formålet med artiklen at undersøge, hvilke opfattelser af værdi der stod på spil i debatten om prioriteringsmodellen, og hvordan de bidrog til at forme det politiske mulighedsrum.

Analysen viser, hvordan fortalere og kritikere italesatte forskellige forståelser af, hvad der udgør relevant ekspertise, acceptable fordelingsprincipper og en legitim basis for prioriteringsbeslutninger. I artiklen argumenteres det, at denne dissonans har været med til at forme, hvad der blev politisk mulige løsninger. I et forsøg på at integrere forskellige opfattelser af værdi lægger prioriteringsmodellen op til, at der skal foretages sundhedsøkonomiske evalueringer - men uden mulighed for at benytte gængse sundhedsøkonomiske metoder til at sammenholde effekt og omkostninger. Endelig diskuteres det, hvilke implikationer det kan have for operationaliseringen af prioriteringsmodellen og politiske målsætninger om prisreduktioner.

\section{Analytisk og metodisk tilgang}

Debatten om prioriteringsmodellen analyseres som et eksempel på, hvad Hanne Foss Hansen og Olaf Rieper (2011) kalder evidenspolitik. Det vil sige en form for politik, som vedrører konflikter om, hvad der konstituerer potentielt anvendelig viden for at træffe kollektivt bindende beslutninger (Hansen \& Rieper 2011). Videnskab spiller ofte ind i spørgsmål om magt, retfærdighed, etik og gruppeidentitet, og når sådanne spørgsmål bliver kontroversielle, kan videnskab blive en arena for politisk debat (Brown 2015). Når aktører i diskussionerne henviser til, hvad der er 'nyttigt', 'ønskværdigt', 'rigtigt', 'acceptabelt' etc., er de med til at skabe bestemte opfattelser af, hvad der er værdifuldt. I situationer, hvor der opstår modstrid eller usikkerhed om, hvilke værdier der gælder - hvad David Stark (2009) kalder dissonans - må aktører aktivt begrunde deres opfattelser af værdi. Gennem sådanne begrundelser bliver det muligt at studere værdier og de grundlæggende idéer om, hvad der er godt, rigtigt, væsentligt etc., som de udtrykker. Inden for Science and Technology Studies-traditionen er der udviklet en gren af 'værdi-studier' (valuation studies) (fx Dussauge et al. 2015), der trækker på ameri- 
kansk pragmatisme (Dewey 1939). I tråd med disse studier opfattes 'værdi' i denne artikel som noget, der aktivt skabes gennem stadig forhandling. Hvad der anses som gældende værdier, forstås altså som resultat af en kamp for at etablere bestemte opfattelser af, hvad der er værdifuldt. Jeg er derfor interesseret i, hvordan forskellige og eventuelt modstridende opfattelser af, hvad der er værdifuldt, interagerer i debatten om prioriteringsmodellen - ikke for at afgøre, hvilke opfattelser der er de 'rette', men for at forstå, hvordan det påvirker de politiske handlemuligheder. Analytisk betyder det, at jeg ikke på forhånd har defineret kategorier for, hvad der er 'værdifuldt', men lader empirien være styrende for, hvilke kategorier der fremdrages.

For at forstå hvad der er på spil for aktørerne i debatten om prioriteringsmodellen, er det nødvendigt også at se mere detaljeret på diskussionerne om vidensgrundlaget for lægemiddelprioritering. For at kunne gøres til genstand for sammenlignende analyse må lægemidler kategoriseres på forskellig vis (Sjögren \& Helgesson 2007). Medicinske behandlinger er altså ikke nødvendigvis sammenlignelige per se, men skal gøres sammenlignelige, eksempelvis ved at opgøre behandlingsresultater og -omkostninger ved hjælp af standardiserede mål. Tilvejebringelsen af vidensgrundlag for lægemiddelprioritering involverer dermed et arbejde med at skabe kommensurabilitet (Espeland \& Stevens 1998), det vil sige et arbejde med at gøre lægemidler evaluerbare i forhold til en fælles skala. Gennem dette arbejde udtrykkes også værdier, fordi det er med til at forme, hvad der tæller som relevante beslutningsgrundlag og opfattes som sammenlignelige alternativer. Eksempelvis har læger, lægemiddelmyndigheder, lægemiddelvirksomheder og patienter ikke nødvendigvis samstemmende opfattelser af, hvad der udgør 'ligeværdige' behandlingsvalg (Wadmann \& Bang 2015). Afvisning af kommensurabilitet kan derfor også forstås som en politisk respons i den forstand, at aktører herved giver udtryk for, at de ikke ser det som et passende eller retvisende udtryk for værdi (Espeland \& Stevens 1998).

Analysen er baseret på offentligt tilgængelige dokumenter om lægemiddelprioritering og Medicinrådet. Via Infomedia er der søgt efter omtale af Medicinrådet i landsdækkende dagblade, radio- og tv-indslag (oktober 2015-november 2016). Desuden er relevante artikler i fagbladene Dagens Pharma og Altinget blevet identificeret, og der er søgt efter dokumenter via bl.a. Danske Regioners og Sundheds- og Ældreministeriets hjemmesider. I analysen beskrives først Danske Regioners udspil og det mulighedsrum for lægemiddelprioritering, de søgte at etablere. Dernæst beskrives hovedpunkter i den kritik, som blev rejst i den offentlige debat, og i lyset heraf redegøres der for justeringerne af prioriteringsmodellen. For at forstå, hvorfor prioriteringsmodellerne i Norge og Sverige tilsyneladende ikke var accepterede inspirationskilder, stiller det sidste afsnit skarpt på den del af debatten, som fokuserede på effektmålet kvalitetsjusterede leveår (quality-adjusted life-years, QALY). 
Regionernes udspil

"Kongstanken" med prioriteringsmodellen blev af regionernes formandskab præsenteret som et ønske om at "[bruge] landets sundhedskroner bedre, så de gavner endnu flere patienter" (Hansen \& Stenbæk 2016, s. 26). Formanden uddybede, at "patienterne" efter hans opfattelse har "krav på", at "midlerne [fordeles], så de kommer flertallet til gode" (Hansen 2016, s. 7). Hermed udtrykte formanden, at efficient ressourceudnyttelse og fordeling af offentlige ressourcer ud fra flertallets bedste udgør centrale værdier i forhold til lægemiddelprioritering. Dermed begrundede han behovet for prioriteringsmodellen ud fra en utilitaristisk opfattelse af, hvad der er værdifuldt: det, der er til størst gavn for de fleste. Idéen er kort fortalt, at alle vil blive bedre stillet, hvis samfundets samlede nytte maksimeres (Wulff, Pedersen \& Rosenberg 2003). Ifølge Danske Regioners notat af 5. februar 2016 er formålet med prioriteringsmodellen desuden at sikre "hurtig og ensartet ibrugtagning af nye sygehuslægemidler på tværs af sygehuse og regioner", "større krav til dokumentationen" for medicinens "gavn" og et "stærkere grundlag" for prisforhandlinger og udbud (Danske Regioner 2016e). Dermed blev også hurtig ibrugtagning, geografisk lighed $i$ behandlingsudbud og mulighed for prispres italesat som væsentlige værdier.

Dette skulle opnås via ændringer i den eksisterende beslutningsstruktur og vidensgrundlaget for prioriteringsbeslutninger. Ændringen i beslutningsstrukturen indebar en sammenlægning af de daværende råd - Koordinationsrådet for ibrugtagning af sygehusmedicin (KRIS) og Rådet for Anvendelse af Dyr Sygehusmedicin (RADS) - i ét medicinråd (Medicinrådet) (Danske Regioner 2016e). Ifølge Danske Regioners oplæg skal Medicinrådet favne lægelig og farmakologisk ekspertise og inddrage hovedinteressenter på området. På baggrund af "politisk givne rammer" skal det træffe "uafhængige beslutninger" om, hvorvidt ny medicin skal tages i brug som "standardbehandling" på hospitalerne (Danske Regioner 2016e). Her italesættes uafhoengighed som en væsentlig værdi i relation til prioriteringsbeslutninger. I tråd hermed udtrykte regionsformanden behov for "en procedure, hvor det faglige grundlag er bærende for, om en ny medicin skal tages i brug - og ikke en afstemning i et regionsråd" (Nielsen 2016a). Regionsformanden lagde altså op til, at prioriteringsbeslutninger ikke skal bygge på politiske præferencer, men faglige vurderinger. Dermed begrundede han prioriteringsmodellen med et behov for objektivitet, som ofte knyttes sammen med ambitioner om evidensbaseret beslutningstagning (jf. Greenhalgh \& Russell 2009).

KRIS og RADS har tidligere foretaget lægefaglige vurderinger af sygehusmedicin, og en del af metodikken herfra videreføres i Medicinrådet. Det nye består dels i, at Medicinrådet skal kategorisere lægemidler med hensyn til deres "merværdi", dels i at regionernes indkøbscentral, Amgros, skal foretage en sundhedsøkonomisk analyse. Merværdi defineres af Danske Regioner som "den ekstra værdi et lægemiddel tilbyder i forhold til nuværende behandling med hensyn til livsforlængelse, bivirkninger og livskvalitet" (Danske Regioner 2016e). Her forstås merværdi altså som den behandlingsmæssige gevinst, som et lægemiddel giver i forhold til eksisterende alternativer. I den 
henseende er den danske model af tysk islæt. I tråd med det tyske analyseinstitut IQWIG (Højgaard et al. 2016) lægger Danske Regioner op til, at Medicinrådet skal placere lægemidler i én af seks kategorier for merværdi: 1) 'stor merværdi', 2) 'vigtig merværdi', 3) 'lille merværdi', 4) 'ingen merværdi', 5) 'negativ merværdi' og 6) 'ikkedokumenterbar merværdi' (Danske Regioner 2016e). Dermed foretages en kategorisering og rangering af lægemidler, som gør dem evaluerbare med hensyn til deres behandlingsmæssige værdi (jf. Sjögren \& Helgesson 2007). Denne kategorisering gør det muligt at tale om, at ikke alle lægemidler tilbyder lige stor merværdi, og at nogle lægemidler kan have negativ merværdi forstået på den måde, at deres behandlingsmæssige gevinst er ringere end eksisterende behandlingsmuligheder. Dermed søger Danske Regioner at skabe et mulighedsrum, hvor 'mere værdifulde' behandlinger kan skelnes fra 'mindre værdifulde'.

I regionernes udspil lægges der desuden op til, at Amgros "forbereder en sundhedsøkonomisk analyse [...] baseret på den faglige kategori og lægemidlets afledte omkostninger" (Danske Regioner 2016e). Formålet med analysen er ifølge regionerne at "vurdere og beregne, hvilket prisinterval man vil kunne acceptere" i Amgros' prisforhandlinger med lægemiddelvirksomhederne (Danske Regioner 2016e). Det blev dog ikke specificeret, hvordan omkostningerne skulle forholdes til den behandlingsmæssige merværdi for at nå frem til det 'acceptable' prisinterval. Efter at være blevet orienteret af Amgros om forhandlingerne skulle Medicinrådet udarbejde en anbefaling til regionerne efter et enkelt princip: Hvis den forhandlede pris var "lavere eller lig det beregnede prisinterval", skulle Medicinrådet fremsende en anbefaling om, at "lægemidlet skal tilbydes som standardbehandling eller protokolleret ibrugtagning", det vil sige, at lægemidlet indføres som behandlingstilbud for en patientgruppe i en given periode, mens der samles data om brugen og virkningerne (Danske Regioner 2016d). Hvis prisen derimod var højere, skulle Medicinrådet "meddele, at lægemidlet ikke kan anbefales ibrugtaget som standardbehandling" (Danske Regioner 2016e). Regionernes udspil lagde dermed op til, at en ny ekspertgruppe - sundhedsøkonomer i Amgros - skulle få væsentlig indflydelse på anbefalinger om at tage ny sygehusmedicin i brug. Ifølge udspillet skal de beregne det 'acceptable prisniveau', der forekommer at være et afgørende kriterium for en positiv eller negativ anbefaling. Dermed udtrykkes ikke blot opfattelser af, hvad der anses for værdifuldt i relation til lægemiddelprioritering, men også hvilken ekspertise det er relevant at inddrage for at opnå viden om, hvad der værdifuldt.

Opsummerende kan udspillet om Medicinrådet forstås som et forsøg på at etablere et politisk mulighedsrum, hvor ibrugtagning af sygehusmedicin kan prioriteres på basis af klare anbefalinger, som hviler på faglige, uafhængige vurderinger af lægemidlers behandlingsmæssige merværdi og behandlingsomkostninger. Når dette er væsentligt for Danske Regioner, hænger det blandt andet sammen med, at regionernes udgifter til sygehusmedicin næsten er fordoblet siden 2007 (Toft 2015). En medvirkende årsag til stigningen er ibrugtagning af nye lægemidler, som er blevet højt prissat. Eksempelvis er kræftlægemidlet Ipilimumab markedsført i Danmark til en pris, der fører til gennemsnitlige behandlingsomkostninger på omkring 800.000 kr. pr. patient. Det er derfor for- 
bundet med væsentlig budgetpåvirkning for regionerne at tage ny sygehusmedicin i brug. Når der er tale om nye behandlingsprincipper, har regionerne desuden begrænset mulighed for at skabe prispres, når der ikke er et grundlag, hvorudfra det kan vurderes, om et lægemiddel er 'prisen værd'. Danske Regioner har tidligere søgt at slå til lyd for tydeligere prioritering på lægemiddelområdet, men uden at opnå landspolitisk opbakning. Dette var tydeligt i valgkampen i forsommeren 2015, hvor statsministerkandidater fra begge fløje ( $\mathrm{S}$ og V) forsikrede borgerne om, at man ville sikre adgang til ny sygehusmedicin - uanset prisen (Lynge 2015, Vangkilde \& Rasmussen 2015). Historisk er der eksempler på, at landspolitikere efter kritisk pressedækning og appel fra patientforeninger har ændret anbefalinger om brugen af specifikke lægemidler. ${ }^{1}$ Derfor var det væsentligt for regionerne at opnå opbakning til prioriteringsmodellen.

\section{Modtagelsen af Danske Regioners udspil}

Regionernes udspil blev genstand for betydelig debat i dagspressen. Lægeforeningen, som aktivt havde bidraget til at sætte prioritering på den sundhedspolitiske dagsorden, udtrykte ikke overraskende opbakning til Danske Regioners initiativ. Lægeforeningens formand fremhævede, at det vil "understøtte en mere fair fordeling af ressourcerne" og sikre, at "patienterne samlet set får mere sundhed for pengene" (Ritzau 2016). Formanden begrundede dermed også opbakningen til udspillet ud fra en utilitaristisk opfattelse af værdi. Lægemiddelindustriforeningen (Lif) forholdt sig afventende, men udtalte bekymring om at prioriteringsmodellen kan forsinke patienters adgang til ny medicin (Holst \& Toft 2016). Her fremhæves hurtig ibrugtagning igen som en væsentlig værdi i relation til lægemiddelprioritering - men denne gang som en bekymring om, at den kan være truet. Med særlig kritisk stemme talte landets store patientforeninger. Formanden for Danske Patienter bemærkede, at "et medicinråd kan være meget fornuftigt", men fandt det "stærkt problematisk", at "den faglige vurdering" af et nyt lægemiddel efter hans opfattelse blev overgivet til "økonomerne i Amgros", som "i et mørkt rum" kan "bedømme, om det er prisen værd" (Nielsen 2016a, s. 12). I tråd hermed udtrykte en række patientforeninger $i$ et fælles debatindlæg bekymring om, at "sundhedsøkonomer og købmænd" efter deres opfattelse "i realiteten [ville] træffe beslutninger om, hvilke medicinske behandlinger [...] der kan accepteres i det danske sundhedsvæsen" (Engberg et al. 2016, s. 27). Uagtet at der i Danske Regioners udspil blev lagt op til, at sundhedsøkonomisk analyse skulle supplere Medicinrådets vurdering af den behandlingsmæssige merværdi, fremhævede disse patientforeninger, hvad de opfattede som en uac-

\footnotetext{
${ }^{1}$ Eksempelvis besluttede den daværende SR-regering mod amternes anbefaling i 1999, at patienter med fremskreden sclerose skulle have tilbudt behandling med lægemidlet betainterferon. Behandlingsudgifterne for de omkring 2.000 patienter blev anslået til 100-200 mio. kr. pr. år. I 2011 blev en anbefaling fra Kræftstyregruppen om ikke at tilbyde lægemidlet avastin som standardbehandling til lungekræftpatienter omstødt efter kritisk medieomtale. Behandlingen var i første omgang blevet afvist, fordi behandlingen i gennemsnit koster 100.000 kr. pr. patient, og der var dokumenteret en gennemsnitlig livsforlængelse på fire måneder.
} 
ceptabel placering af beslutningskompetence hos Amgros-ansatte sundhedsøkonomer. Hermed udtrykte patientforeningerne også opfattelser af, hvem der skal have legitim indflydelse på prioriteringsbeslutninger. Men modsat regionernes udspil bestred patientforeningerne legitimiteten af sundhedsøkonomisk indflydelse. De argumenterede i stedet for, at beslutninger om ibrugtagning af lægemidler bør hvile på klinisk ekspertise og fremførte, at såfremt det er nødvendigt at afvise ibrugtagning af ny sygehusmedicin, bør det ske "i en åben debat i et medicinråd med efterfølgende politisk beslutning" (Engberg et al. 2016, s. 27). I kontrast til regionsformandens betoning af faglighed frem for politiske præferencer argumenterede patientforeningerne altså for, at prioritering netop er et politisk anliggende. Mens regionsformanden lagde op til, at legitimiteten af prioriteringsbeslutninger bør hvile på fagkundskab, fordi det kan bidrage til at sikre en efficient allokering af offentlige ressourcer, lagde patientforeningerne op til, at legitimiteten af prioriteringsbeslutninger bør hvile på demokratisk repræsentation, fordi folkevalgte har mandat til at fordele offentlige ressourcer. Patientforeningerne søgte dermed også at påvirke det politiske mulighedsrum. Ved at italesætte den sundhedsøkonomiske indflydelse på prioritering af sygehusmedicin som illegitim stillede de spørgsmålstegn ved den centrale nyskabelse i Danske Regioners udspil.

Med henvisning til at de sundhedsøkonomiske analyser skulle foregå i et 'mørkt rum', udtrykte formanden for Danske Patienter bekymring for, at grundlaget for prioriteringsbeslutninger skulle savne transparens. Mere direkte hævdede en række patientforeninger, at regionernes prioriteringsmodel ville indebære, at "man ikke kan få indsigt i, hvad det er for beregninger, der er foretaget, og hvad det er for antagelser, sundhedsøkonomerne i Amgros har gjort sig" (Engberg et al. 2016, s. 27). Udtalelserne kan forstås i lyset af, at Danske Regioners udspil ikke beskriver det metodiske grundlag for lægemiddelvurderingerne, eftersom det netop var et udspil. Mere generelt udtrykte de også en opfattelse af transparens som værdifuldt i lægemiddelprioritering - men en værdi som ifølge patientforeningerne kunne være truet. Videre stillede formændene for Kræftens Bekæmpelse og Dansk Selskab for Klinisk Onkologi sig spørgende over for, hvor "grænsen går" i forhold til det 'acceptable prisinterval', og hvor "meget syge patienter, som kan have gavn af en behandling, som er meget kostbar" står i den forbindelse (Crüger \& Lassen 2016, s. 9). Hermed udtrykte de bekymring for, hvordan individuelle behov tilgodeses, hvis sygehusmedicin skal prioriteres ud fra et princip om størst gavn for flertallet. I kontrast til den utilitaristiske opfattelse af værdi i regionernes udspil italesatte de en pligtetisk opfattelse af, hvad der er værdifuldt: det der gøres med henblik på at hjælpe den, der har behov (Wulff, Pedersen \& Rosenberg 2003). Gennem italesættelsen af en kontrasterende opfattelse af værdi søgte patientforeningerne altså at etablere en anden målestok for vurdering af værdi end den, som regionerne lagde op til: En målestok som betoner individets behov.

Blandt landspolitikerne var modtagelsen blandet. SF og R roste regionernes initiativ, mens DF forholdt sig kritisk. Den Venstre-ledede regering og socialdemokraterne pointerede, at prioritering ikke kun er et anliggende for regionerne, fordi sager kan ende på sundhedsministerens bord (Nielsen 2016b). Knap to måneder senere præsenterede et 
enigt Folketing (FT) en landspolitisk ramme i form af "7 overordnede principper for prioritering på området for sygehuslægemidler" (Sundheds- og Ældreministeriet 2016). Flere af prioriteringsprincipperne har direkte reference til Danske Regioners udspil og udtrykker dermed de samme værdier, herunder at vurdering af lægemidler skal hvile på faglighed og uafhoengighed via brug af "objektive kriterier" og inddragelse af den "nødvendige og tilstrækkelige faglige ekspertise. Derudover at der skal sikres geografisk lighed, hurtig ibrugtagning af nye lægemidler samt mere efficient ressourceudnyttelse, idet forholdet mellem et lægemiddels "pris" og dets behandlingsmæssige "merværdi" skal være "rimeligt", hvis det være "standardbehandling". Dermed blåstemplede folketingspolitikerne, at omkostninger inddrages i vurderingen af ny sygehusmedicin. Samtidig slog de dog fast, at omkostningerne ikke kan være det afgørende kriterium, hvis der er en klar behandlingsmæssig merværdi, idet lægemidler med "veldokumenteret mereffekt ikke [skal] afvises alene på grund af økonomi”. I tråd med patientforeningernes udtalelser blev transparens fremhævet som en væsentlig værdi, der skal sikres via åbenhed i processer, kriterier, metoder mv. Endelig blev der også italesat et behov for at tilgodese individuelle behandlingsbehov. FT fastslog, at der "ud fra en konkret lægefaglig vurdering" skal være mulighed for at "behandle med lægemidler, som er afvist til standardbehandling" (Sundheds- og Ældreministeriet 2016, s. 2). Mens Danske Regioners udspil lagde op til, at prioriteringsbeslutninger skal træffes centralt og tilgodese flertallets interesser, blev der her skabt rum for, at læger kan afvige fra Medicinrådets anbefalinger af hensyn til den enkelte patients interesser. Dermed inkorporerede prioriteringsprincipperne også den pligtetiske opfattelse af værdi, som patientforeningerne italesatte. I lyset af debatten og drøftelser med interessenter præsenterede Danske Regioner i april 2016 en justeret prioriteringsmodel.

Justering af prioriteringsmodellen

Justeringen indebar ifølge regionernes formand, at "økonomien er trængt lidt i baggrunden, mens den lægelige faglighed er kommet mere i forgrunden” (Nielsen 2016c, s. 2). Konkret kommer det til udtryk ved en mindre ændring af rådets sammensætning, hvorved Danske Regioner forventede, at "minimum 16 ud af 20 medlemmer" af rådet ville have "lægefaglig baggrund" (Danske Regioner 2016b, s. 1). Derudover blev der lagt op til, at 46 eksisterende fagudvalg med "landets førende læger" (Danske Regioner 2016b) overgår fra RADS til Medicinrådet, som skal høre relevante fagudvalg ved kategoriseringen af lægemidlernes merværdi (Danske Regioner 2016c). Samtidig blev Medicinrådets kompetence styrket. Det sker ved, at rådet gives mulighed for at "foretage en efterprøvning af forholdet mellem lægemidlets pris og merværdi" i tilfælde, hvor den forhandlede pris overstiger det 'acceptable prisinterval' (Danske Regioner 2016d, s. 4). Hermed lægges der op til, at den endelige vurdering af, hvorvidt forholdet mellem merværdi og omkostninger er acceptabelt, ligger hos Medicinrådet. Justeringen betyder også en udvidelse af udfaldsrummet for Medicinrådets anbefalinger, idet der åbnes mu- 
lighed for, at Medicinrådet kan lave anbefalinger om begrænset ibrugtagning, eksempelvis ved at anbefale ibrugtagning for en snævrere behandlingsindikation eller en afgrænset patientgruppe (Danske Regioner 2016d). Dermed skabes der rum for, at nye lægemidler kan tages $\mathrm{i}$ brug til afgrænsede patientgrupper uden at blive udbredt som standardbehandling for alle med en given lidelse. Desuden fastslår Danske Regioner, at det fortsat "er op til den enkelte læge at vurdere, hvilken medicin der er bedst for den enkelte patient", men at det kræver "en faglig begrundelse at afvige" fra Medicinrådets anbefalinger (Danske Regioner 2016d, s. 6). Dermed lægges der op til, at patienter også kan få adgang til lægemidler, som ikke anbefales som standardbehandling, hvis en behandlende læge vurderer det nødvendigt. Dette skal ses i lyset af, at de landspolitiske prioriteringsprincipper lægger op til, at prioriteringsmodellen både skal kunne optimere nytten for de fleste $o g$ tilgodese individuelle behov. Med muligheden for at anbefale begrænset brug og princippet om den fri ordinationsret søgte Danske Regioner at håndtere den potentielle spænding mellem disse kontrasterende opfattelser af værdi.

Endelig er det i regionernes reviderede udspil tydeliggjort, hvordan transparens skal sikres. Det fremgår bl.a., at kommissorium, dagsordner, mødereferater og høringsmateriale i forbindelse med Medicinrådets vurderinger offentliggøres (Danske Regioner 2016f). Endvidere er der udkast til metodevejledninger for vurderingen af behandlingsmæssig merværdi samt den sundhedsøkonomiske analyse. Deraf fremgår det, at den sundhedsøkonomiske analyse er en "omkostningsanalyse", som vurderer de "inkrementale omkostninger" ved ibrugtagning af et nyt lægemiddel (Amgros 2016; Danske Regioner 2016c). Tilbage står imidlertid fortsat spørgsmålet om, hvordan behandlingsmæssig merværdi og omkostninger skal sammenvejes for at nå frem til det 'acceptable prisniveau'. Som en professor i sundhedsøkonomi konstaterede, gav den reviderede model fortsat intet bud på, hvordan Medicinrådet og Amgros "helt konkret [skal] vurdere, om lægemidlernes effekt står i rimeligt forhold til deres pris på en systematisk og ensartet måde" (Hildebrandt 2016a). Professoren efterlyste et "standardiseret outcomemål", der kan bidrage til at "operationalisere", hvad vi i Danmark er villige til at betale for lægemidler med større eller mindre behandlingsmæssig merværdi. For at forstå væsentligheden af dette må vi tæt på den del af debatten, som handler om sundhedsøkonomiske metoder. Gennem analyse af den kontrovers, der udspillede sig om effektmålet QALY, peges i det følgende på mulige grunde til, at Medicinrådet og Amgros er blevet ladt uden mulighed for at benytte et af de mest udbredte sundhedsøkonomiske mål til vurdering af lægemidlers omkostningseffektivitet.

\section{Kampen om QALY}

Gennem de seneste 50 år har sundhedsøkonomer arbejdet på at udvikle metoder til at opgøre og sammenligne medicinske behandlingers værdi (Nord 1999). En metode til at sammenholde lægemidlers behandlingsmæssige effekter med behandlingsomkostnin- 
gerne er via analyse af omkostningseffektivitet. ${ }^{2}$ Her formuleres spørgsmålet om lægemidlets værdi som et spørgsmål om, hvorvidt forholdet mellem de forventede behandlingseffekter og de forventede behandlingsudgifter er gunstigt set i forhold til relevante behandlingsalternativer. På den måde har sundhedsøkonomer søgt at skabe grundlag for at vurdere, hvilke lægemidler der kan siges at være mest omkostningseffektive. Forsimplet er idéen, at valget af de mest omkostningseffektive behandlinger vil føre til den mest efficiente brug af offentlige ressourcer (Drummond et al. 2005). Dette fokus på ressourcefordeling bygger på en forståelse af, at ressourcerne i sundhedsvæsenet er knappe, og at der er risiko for, at nye, dyre lægemidler fortrænger andre lægemidler, som er mere omkostningseffektive, hvis man ikke har måder at vurdere, hvilke lægemidler der giver 'mest effekt for pengene'. Problemet handler i denne optik om at undgå unødigt ressourceforbrug (jf. Moreira 2012). Da man sammenligner omkostninger pr. effektenhed, kræver analysen, at effekten af forskellige behandlinger opgøres i samme enhed (Drummond et al. 2005). Analyse af omkostningseffektivitet involverer altså et arbejde med at skabe kommensurabilitet forstået på den måde, at lægemidlernes virkninger udtrykkes ved hjælp af en fælles måleenhed (jf. Espeland \& Stevens 1998). Medicinsk behandling kan ikke blot have betydning for dødelighed men også sygelighed. Mål for sygelighed varierer imidlertid ofte mellem sygdomsgrupper. Det var en del af afsættet for, at sundhedsøkonomer i 1970'erne søgte at udvikle nye mål, som kunne udtrykke effekten af medicinsk behandling ikke blot i relation til livslængde men også livskvalitet, og som muliggjorde sammenligning på tværs af behandlingsområder (se Moreira 2012). Effektmålet, som har vundet størst udbredelse, kaldes kvalitetsjusterede leveår (Weinstein \& Stason 1977). Simpelt fortalt består 'kvalitetsjusteringen' i, at levetiden, som patienter kan tilbringe i forskellige helbredsstadier, vægtes ud fra, hvor foretrukne helbredsstadierne er. Vægtene er fremkommet ved at lade en gruppe personer vurdere forskellige helbredstilstande på en skala fra 0 (defineret som død) til 1 (defineret som perfekt helbred) ud fra deres præferencer (Drummond et al. 2005). Gennem denne kategorisering af helbredstilstande bliver det muligt at integrere forskellige kliniske effekter i en fælles skala for den oplevede ønskværdighed af livet $i$ en given helbredstilstand. Derved kan omkostninger pr. effektenhed sammenlignes for forskellige behandlinger - også selvom behandlingerne giver anledning til forskellige slags kliniske effekter. Gennem denne kategorisering har sundhedsøkonomer altså søgt at skabe kommensurabilitet mellem medicinske behandlinger, som ikke nødvendigvis er sammenlignelige ud fra kliniske standarder.

Omkostninger pr. QALY udtrykker relativ - ikke absolut - omkostningseffektivitet. Derfor tilbyder målet ikke i sig selv svar på, hvad de 'acceptable' behandlingsomkostninger er (Sjögren \& Helgesson 2007). For at kunne afgøre om et nyt lægemiddel er 'prisen værd', behøves derfor et vurderingsgrundlag. Grundlæggende handler det om,

\footnotetext{
${ }^{2}$ En anden evalueringsteknik er omkostningsminimeringsanalyse. Metoden kan bruges til at drage simple sammenligninger mellem lægemidler, som vurderes ensartede med hensyn til klinisk effekt, men ikke til at vurdere, hvorvidt lægemidler, som er dyrere men også mere effektfulde end eksisterende behandlinger, er 'prisen værd'.
} 
hvad et samfund vil acceptere at betale for en given behandlingsmulighed. Vurderingsgrundlaget er i England, Norge og Sverige udtrykt ved et mere eller mindre eksplicit defineret niveau for de 'acceptable' omkostninger pr. QALY. Niveauet er ikke at forstå som en politisk vedtaget grænseværdi, men snarere som et niveau, der er opnået præcedens om via konkrete beslutninger. Niveauet kan desuden variere $i$ forhold til andre kriterier såsom sygdomsalvor (Højgaard et al. 2016). Dermed er det ikke blot hensynet til omkostningseffektivitet, som informerer prioriteringsbeslutninger i disse lande, selvom den offentlige debat i Danmark kan give det indtryk. Ved at skabe et grundlag for vurderingen af nye lægemidler, som inkluderer omkostningerne, er det erfaringen fra England, Norge og Sverige, at der skabes et bedre udgangspunkt for prisforhandlinger med lægemiddelvirksomheder, og i nogle tilfælde opnås prisreduktioner (Højgaard et al. 2016). Åbenhed om niveauet for de 'acceptable' omkostninger pr. QALY indebærer imidlertid en risiko for strategisk prissætning. Sundhedsmyndighederne søger derfor typisk at holde informationen konfidentiel. I England, hvor man siden slutningen af 1990'erne har benyttet QALY-baseret omkostningseffektivitetsanalyse i lægemiddelvurderinger, har der været rejst kritik af, at det kun var den offentlige vurderingsinstitution the National Institute for Clinical Excellence, NICE, der havde adgang til de fulde økonomiske modeller (Moreira 2012). Hensynet til at skabe prispres og efficient brug af offentlige ressourcer kan dermed have betydning for mulighederne for at sikre transparens i grundlaget for prioriteringsbeslutninger (Højgaard et al. 2016).

Brugen af QALY i prioriteringsmodeller i flere europæiske lande kan tages som udtryk for en vis institutionalisering af effektmålets brug ved lægemiddelprioritering. I Danmark er brugen af QALY desuden skrevet ind i Lægemiddelstyrelsens retningslinjer for samfundsøkonomiske analyser af lægemidler (Alban, Keiding \& Søgaard 1998), der gennem flere år har støttet vurderingen af lægemidler i praksissektoren. På trods heraf har en del af modstanden mod prioritering af sygehusmedicin i Danmark været koncentreret netop om QALY. I dagspressen er QALY blevet omtalt som en metode til at "sætte pris på et menneskeliv" (Winther \& Thorup 2012a). Med udgangspunkt i patienthistorier har patienter, patientforeninger og Etisk Råd advaret mod at "sætte menneskeliv på formel" og "miste mennesket i regnestykket" (se eksempelvis Kjeldtoft 2016, Winther \& Thorup 2012a, Winther \& Thorup 2012b). Dermed fremlægges brugen af QALY som en metode til at vurdere, hvorvidt det er 'værd' at investere i behandlingen af givne patienter. Kritikken kan forstås som en afvisning af den kommensurabilitet mellem medicinske behandlinger, som brugen af et standardiseret effektmål lægger op til. Ifølge disse kritikere indebærer standardiseringen en risiko for, at individuelle behandlingsbehov ikke kan tilgodeses. På den baggrund italesættes det som en moralsk betænkelig praksis. Sundhedsøkonomer har kaldt denne fremlægning for "misforstået" og et "udtryk for uvidenhed" og har betonet, at brugen af QALY handler om at få mest muligt ud af de fælles ressourcer (Hildebrandt 2016a). Her udtrykkes altså atter en spænding mellem en pligtetisk og en utilitaristisk opfattelse af værdi. Endvidere rejste kritikere en metodekritik. Fra Kræftens Bekæmpelse blev det fremhævet, at QALY kan være behæftet med "betydelig måleusikkerhed", og at der sjældent er "én entydig empirisk be- 
stemmelse af en QALY", fordi vægtningen af helbredstilstande kan variere fra kontekst til kontekst (Hildebrandt 2016b). Hermed stillede patientforeningen spørgsmålstegn ved validiteten af effektmålet. Videre blev det fra Kræftens Bekæmpelse bemærket, at sundhedsøkonomi ikke er en "eksakt" videnskab, men en kompliceret "adfærdsvidenskab", hvorfor de fandt, at prioritering på basis af sundhedsøkonomiske metoder "aldrig [kan] blive $100 \%$ objektiv" (Hildebrandt 2016b). Dermed betvivlede patientforeningen regionernes argument om, at prioriteringsmodellen skulle sikre objektivitet. Endelig blev det fra patientforeningen kommenteret, at brugen af en 'QALY-model' vil kunne betyde, at "kritikerne får ret $\mathrm{i}$, at det er sundhedsøkonomerne og ikke læger og politikere, som bestemmer" (Hildebrandt 2016b). Det kan forstås i lyset af, at det for sundhedsøkonomiske - såvel som andre - analyser af lægemidlers værdi er en præmis, at de hviler på bestemte antagelser om, hvad der er værdifuldt. For de, som ikke har indsigt i metoderne, kan det være uigennemskueligt, på hvilket grundlag en prioritering er foretaget. Her bruges argumentet om transparens altså med omvendt fortegn: Brugen af et standardiseret effektmål såsom QALY vil ikke skabe større transparens, fordi kun sundhedsøkonomer besidder den relevante ekspertise til at forstå beregningerne. Det ræsonnerer med en fremsat kritik af idéen om evidensbaseret politik: at 'politiske' problemer gøres til 'tekniske anliggender', hvorved demokratisk kontrol vanskeliggøres (Greenhalgh \& Russel 2009).

Via kritikken af QALY søgte kritikerne at drage tvivl om legitimiteten af de modeller for lægemiddelprioritering, som benyttes i lande som Norge, Sverige og England. Sammen med italesættelsen af QALY som en metode til at 'sætte pris på menneskeliv' kan det bidrage til at forklare, at der i Danmark opstod politisk modstand mod brugen af QALY. Den nyudnævnte formand for Medicinrådet omtalte således et politisk "forbud" mod anvendelsen af QALY ved vurdering af sygehusmedicin (Hildebrandt 2016a). Det betyder, at regionerne ikke har kunnet skele til prioriteringsmodellerne i Norge, Sverige og England. Ét af de særlige danske forhold, som Danske Regioner har måttet tage hensyn til, synes altså at være politisk modstand mod brugen af QALY.

\section{Diskussion og konklusion}

Danske Regioners model for prioritering af sygehusmedicin kan forstås som et forsøg på at sikre et evidensbaseret grundlag for beslutninger om ressourceallokering. Via en kategorisering af lægemidlers behandlingsmæssige merværdi samt introduktion af sundhedsøkonomisk analyse i lægemiddelvurderinger er det målsætningen at skabe større ensartethed i lægemiddelbehandlingen, mere efficient ressourceudnyttelse, hurtig ibrugtagning af nye lægemidler og mulighed for at opnå prisreduktioner. Mens der blev udtrykt opbakning til disse målsætninger i den offentlige debat, opstod der modstand i forhold til konkretiseringen af prioriteringsmodellen. Analysen har tydeliggjort, hvordan fortalere og kritikere italesatte grundlæggende forskellige opfattelser af, hvad der udgør acceptable fordelingsprincipper, relevant fagekspertise og en legitim basis for 
prioriteringsbeslutninger, og hvordan det knytter an til forskellige problemforståelser i forhold til prioriteringsdebatten. Tabel 1 opsummerer disse opfattelser som to kontrasterende 'idealpositioner' i debatten.

\begin{tabular}{|c|c|c|}
\hline & Fortalere & Kritikere \\
\hline Problemforståelse & $\begin{array}{l}\text { Ressourcerne er knappe. Uden } \\
\text { mekanismer til at vurdere, hvilke } \\
\text { lægemidler der giver mest effekt } \\
\text { for pengene, kan man risikere, at } \\
\text { nye, dyre lægemidler fortrænger } \\
\text { andre lægemidler, som er mere } \\
\text { omkostningseffektive. }\end{array}$ & $\begin{array}{l}\text { Prioriteringsbeslutninger har betyd- } \\
\text { ning for borgernes adgang til be- } \\
\text { handling. Borgernes mulighed for at } \\
\text { opnå indsigt i og påvirke til- og fra- } \\
\text { valg af behandlinger begrænses, } \\
\text { hvis prioriteringsbeslutninger bliver } \\
\text { gjort til et 'teknisk' anliggende. }\end{array}$ \\
\hline $\begin{array}{l}\text { Acceptabelt forde- } \\
\text { lingsprincip }\end{array}$ & $\begin{array}{l}\text { Fordeling af offentlige ressour- } \\
\text { cer, så det skaber størst nytte for } \\
\text { de fleste (utilitarisme). }\end{array}$ & $\begin{array}{l}\text { Fordeling af offentlige ressourcer, så } \\
\text { det hjælper dem med behov. Alle } \\
\text { mennesker har iboende værdi og } \\
\text { derfor samme ret til hjælp og pligt } \\
\text { til at hjælpe (pligtetik). }\end{array}$ \\
\hline $\begin{array}{l}\text { Vidensbehov og } \\
\text { relevant fagkund- } \\
\text { skab }\end{array}$ & $\begin{array}{l}\text { Kræver viden om, hvilke læge- } \\
\text { midler der giver mest 'effekt for } \\
\text { pengene' og er 'prisen værd'. } \\
\text { Derfor opfattes medicinsk og } \\
\text { sundhedsøkonomisk fagkund- } \\
\text { skab som relevant ekspertise. }\end{array}$ & $\begin{array}{l}\text { Kræver viden om, hvem der har } \\
\text { behov for hvilke behandlinger. Der- } \\
\text { for opfattes medicinsk fagkundskab } \\
\text { som relevant ekspertise. }\end{array}$ \\
\hline $\begin{array}{l}\text { Legitim basis for } \\
\text { prioriterings- } \\
\text { beslutninger }\end{array}$ & $\begin{array}{l}\text { Fagkundskab. Eksperter har } \\
\text { fornøden indsigt til at vurdere, } \\
\text { hvad der er en efficient alloke- } \\
\text { ring af offentlige ressourcer. } \\
\text { Objektivitet og uafhængighed } \\
\text { skal sikre, at alle behandles efter } \\
\text { samme principper. }\end{array}$ & $\begin{array}{l}\text { Demokratisk repræsentation. Folke- } \\
\text { valgte er givet mandat til at priorite- } \\
\text { re offentlige ressourcer. Åbenhed } \\
\text { og mulighed for deltagelse skal } \\
\text { sikre, at de, som påvirkes, kan gøre } \\
\text { deres stemme hørt. }\end{array}$ \\
\hline $\begin{array}{l}\text { Beslutningstageres } \\
\text { rolle }\end{array}$ & $\begin{array}{l}\text { Sikre implementering af de do- } \\
\text { kumenteret mest optimale løs- } \\
\text { ninger. }\end{array}$ & $\begin{array}{l}\text { Mediere mellem konkurrerende } \\
\text { interesser }\end{array}$ \\
\hline
\end{tabular}

Tabel 1: Idealpositioner i debatten om prioritering af sygehusmedicin

Problemet, som prioriteringsmodellen skal løse, handler for fortalerne om fordeling af knappe ressourcer. Bekymringen er, at man uden mekanismer til at vurdere, hvilke lægemidler der giver 'mest effekt for pengene', risikerer, at nye dyre lægemidler fortrænger mere omkostningseffektive alternativer. På den baggrund begrundede fortalerne behovet for prioriteringsmodellen ud fra en utilitaristisk forståelse af værdi. Sat på spidsen handler prioritering i denne forståelse om at gavne flest muligt, fordi samfundet derved opnår den største samlede nytte. Derfor er det for fortalerne væsentligt at opnå viden om, hvilke behandlinger der giver mest 'effekt for pengene', og hvilke lægemidler der kan siges at være 'prisen værd'. Gennem denne fremstilling af prioriteringsproblemet søgte fortalerne at åbne rum for, at sundhedsøkonomisk analyse kan informere 
beslutninger om ibrugtagning af sygehusmedicin. Kritikerne stillede sig derimod skeptiske over for prioriteringsmodellens præmis om, at værdi i relation til lægemiddelbehandling handler om at opnå størst nytte for samfundet. Gennem italesættelse af en pligtetisk forståelse af værdi betonede de hensynet til den enkeltes behov. Denne opfattelse bygger på en forståelse af, at alle mennesker har iboende værdi og derfor samme ret til hjælp og pligt til at hjælpe. Ud fra denne forståelse er det væsentlige derfor ikke så meget, hvilke behandlinger der er mest omkostningseffektive, men hvem der har hvilke (behandlings)behov. På den basis betvivlede kritikerne legitimiteten af sundhedsøkonomisk indflydelse på beslutninger om til- og fravalg af lægemidler.

Gennem debatten udtrykkes også forskellige opfattelser af, hvad der udgør legitime grundlag for prioriteringsbeslutninger. Fortalere for prioriteringsmodellen fremførte, at fagkundskab udgør en legitim basis for prioriteringsbeslutninger, idet faglige eksperter forventes at have den fornødne indsigt til at kunne vurdere, hvad der er en efficient allokering af offentlige ressourcer og den uafhængighed og objektivitet, som skal sikre, at alle behandles efter samme principper. Dermed udtrykte de en forståelse af 'gode' beslutninger som uvildige, upartiske og egalitære - en forståelse der genfindes i international debat om sundhedsøkonomiens rolle i politiske beslutningsprocesser. Synspunktet, der har været fremført af ledende sundhedsøkonomer op gennem 19801990'erne er, at sundhedsøkonomisk analyse skal bidrage med afklaring, der kan gøre det muligt for beslutningstagere at hæve sig over enkeltinteresser og foretage, hvad de betegner som mere rationelle fordelingsbeslutninger (jf. Moreira 2012). Dermed udtrykkes en forståelse af beslutningstagere som nogle, der virker på samfundets vegne, ønsker at optimere ressourceanvendelsen, og hvis centrale opgave det er at sikre, at de dokumenteret mest optimale løsninger implementeres. I kontrast hertil udtrykte kritikerne af prioriteringsmodellen bekymring om, at prioritering gøres til et 'teknisk' anliggende. De fremførte, at prioriteringsbeslutninger bør foregå efter åben politisk debat. Dermed italesatte de en opfattelse af, at folkevalgte har legitimt mandat til at prioritere offentlige ressourcer, og at åbenhed og mulighed for deltagelse skal sikre, at interessenter kan gøre deres stemme hørt. Det centrale problem handler altså i kritikernes forståelse om at sikre borgeres og interesseorganisationers mulighed for at opnå indsigt i og påvirke beslutninger, som har direkte betydning for dem. I tråd med kritiske røster i den internationale QALY-debat op gennem 1980-1990'erne udtrykte de dermed en opfattelse af, at 'gode' beslutninger hviler på forhandling mellem konkurrerende interesser, mens forsøg på at 'rationalisere' fordelingsbeslutninger via sundhedsøkonomisk analyse omvendt opfattes som "pseudodemokratisk" og derfor 'uetisk' (Carr-Hill 1991 citeret i Moreira 2012, 77). Gennem italesættelsen af markant andre opfattelser af, hvad der er værdifuldt i relation til lægemiddelbehandling, og hvem der har mandat til at afgøre det, bidrog kritikerne til at forme det politiske mulighedsrum. Ved at italesætte sundhedsøkonomisk ekspertise og gængse sundhedsøkonomiske metoder som 'uetiske' søgte de at afskrive Danske Regioners ønske om at inddrage behandlingsomkostningerne som illegitime. 
En ofte fremført kritik af idéen om evidensbaseret politik er, at den bygger på en forsimplet forståelse af politisk beslutningstagning, der ikke tager hensyn til kontekstafhængighed og forhandlinger mellem interessenter (fx Greenhalgh \& Russel 2009). Denne analyse viser imidlertid, hvordan beslutningsmodellen netop er blevet tilpasset $\mathrm{i}$ lyset af debat mellem centrale aktører, men ironisk nok på en måde, der kan vise sig udfordrende at udmønte i praksis. Mens der blev opnået politisk accept af, at behandlingsomkostninger skal informere prioriteringsbeslutninger, er Medicinrådet og Amgros ladt uden mulighed for at benytte gængse sundhedsøkonomiske metoder til sammenholde effekt og omkostninger. Tilbage står derfor fortsat spørgsmålet om, hvordan den behandlingsmæssige merværdi skal sammenholdes med behandlingsomkostningerne for at nå frem til et 'acceptabelt' prisniveau. Det efterlader Medicinrådet og Amgros med en betydelig udfordring i forhold til at finde ud af, hvordan man i praksis skal operationalisere prioriteringsmodellen, som trådte i kraft 1. januar 2017. Som formanden forklarede: "I Danmark laver vi en model, hvor vi i stedet for at indføre QALY diskuterer priser på baggrund af en kategorisering af lægemidler, som jeg medgiver, endnu er løst defineret", hvorfor Medicinrådet må "høste noget erfaring" for "med tiden blive klogere på, hvordan modellen præcist skal udmøntes" (Hildebrandt 2016a). Tilpasningen har også betydet, at Medicinrådet har fået mulighed for at anbefale begrænset ibrugtagning af nye lægemidler, og det er præciseret, at behandlende læger kan fravige Medicinrådets anbefalinger for at tilgodese enkelte patienters behov. Fremadrettet vil det være væsentligt at følge, hvad dette betyder for muligheden for at opnå prisreduktioner. Det vil afhænge af, hvorvidt det af Medicinrådet opfattes som en reel mulighed at afvise ibrugtagning af nye lægemidler, og hvordan rådets anbefalinger efterleves i praksis. Hvis anbefalinger om ikke at tage givne lægemidler i brug som standardbehandling alligevel fører til spredt ibrugtagning på hospitalerne, vil det formentlig svække mulighederne for at opnå prisreduktioner. Dette gør implementering og opfølgning af Medicinrådets anbefalinger til en meget væsentlig opgave for regionerne.

Tak til

Forfatteren ønsker at takke Betina Højgaard, Claes-Fredrik Helgesson, Jakob Kjellberg, Vibeke Normann-Andersen, en reviewer samt redaktørerne for indsigtsfulde kommentarer og forslag til en tidligere version af artiklen. 
Litteratur

Alban, A., Keiding, H. and Søgaard, J. (1998). Retningslinjer for Samfundsøkonomiske analyser af Logemidler. København: Lægemiddelstyrelsen og DSI.

Amgros. (2016). Metodevejledning for omkostningsanalyser af nye laegemidler og indikationer i hospitalssektoren. København: Danske Regioner.

Brown, M. B. (2015). Politicizing science: Conceptions of politics in science and technology studies. Social Studies of Science, vol. 45, no(1), pp. 3-30.

Carr-Hill, R. (1991). Allocating resources to health care: Is the QALY (Quality Adjusted Life Year) a technical solution to a political problem?. International Journal of Health Services, vol. 21, pp. 351-363.

Crüger, D. and Lassen, U. (2016). Det er tillid til vores læger, regionerne mangler. Politiken, 2. marts 2016, sektion 2, s. 9

Danske Regioner. (2016a). Anvendelse af nye loegemidler, der ikke er blevet anbefalet som standardbehandling af Medicinrådet. Notat af 4.4.2016. København: Danske Regioner.

Danske Regioner. (2016b). Faglighed i Medicinrådet. Notat af 4.4.2016. København: Danske Regioner.

Danske Regioner. (2016c). Model for udarbejdelse af falles regionale vurderinger af nye lagemidlers og nye indikationers kliniske mervardi. Metodehåndbogen. Version 1.0. København: Danske Regioner.

Danske Regioner (2016d). Model for vurdering af logemidler. Notat af 4.4.201. København: Danske Regioner.

Danske Regioner. (2016e). Ny model for vurdering af loegemidler. Notat af 5.2.2016. København: Danske Regioner.

Danske Regioner. (2016f). Transparens i Medicinrådets arbejde. Notat af 4.4.2016. København: Danske Regioner.

Dewey, J. (1939). Theory of valuation. [online] Available at: https://archive.org/stream/theoryofvaluatio032168mbp\#page/n11/mode/2up [Accessed 23 May 2017].

Drummond, M., Jönsson, B., Rutten, F. and Stargardt, T. (2011). Reimbursement of pharmaceuticals: reference pricing versus health technology assessment. European Journal of Health Economics, vol. 12(3), pp. 263-271.

Drummond, M. F., Sculpher, M. J., Torrance, G. W., O’Brien, B. J. and Stoddart, G. L. (2005). Methods for the Economic Evaluation of Health Care Programmes, 3rd ed. Oxford; New York: Oxford University Press.

Dussauge, I., Helgesson, C. F., Lee, F. and Woolgar, S. (2015). On the omnipresence, diversity, and elusiveness of values in the life sciences and medicine. In: I Dussauge, C. F. Helgesson and F. Lee, ed., Value practices in the life sciences and medicine, $1^{\text {st }}$ edition. Oxford: Oxford University Press, pp. 1-30. 
Engberg, L., Henningsen, E., Crüger, D. G., Hansen, H. S., Rendtorff, P., Linde, L. and Holst, M. (2016). Truslen fra den dyre medicin. Berlingske, 9. marts 2016, sektion 1, s. 27.

Espeland, W. N. and Stevens, M. L. (1998). Commensuration as a Social Process. Annual Review of Sociology, vol. 24, pp. 313-343.

Greenhalgh, T. and Russell, J. (2009). Evidence-based policymaking: a critique. Perspectives in Biology and Medicine, vol. 52(2), pp. 304-318.

Hansen, B. (2016). Vi skal sikre mest sundhed for borgerne. Politiken, 7. marts 2016, sektion 2, s. 7.

Hansen, B. and Stenbæk, J. (2016). Bedre behandling til flere patienter. Berlingske, 17. marts 2016, sektion 1, p. 26.

Hansen, H. F. and Rieper, O. (2011). Evidenspolitik - fallet Danmark. In: I. Bohlin and M. Sager, ed., Evidensens många ansikten. Evidensbaserad praktik i praktiken, 1st edition. Lund: Arkiv, pp. 185-205.

Hildebrandt, S. (2016a). Økonom: Svært for Medicinråd at skaffe rabatter. Dagens Pharma, 14. april 2016. Available at: http://dagenspharma.dk/oekonom-svaert-formedicinraad-at-skaffe-rabatter/ [accessed January 15, 2017]

Hildebrandt, S. (2016b). Sundhedsøkonom: Qalyer som et eksakt mål er en illusion. Dagens Pharma, 19. april 2016. Available at: http://dagenspharma.dk/sundhedsoekonom-qalyer-som-et-eksakt-maal-er-enillusion/ [accessed January 15, 2017]

Højgaard, B., Wadmann, S., Jakobsen, M., Rasmussen, S. R., Pedersen, N. J. M. and Kjellberg, J. (2016). Regulering af sygehusmedicin med udgangspunkt $i$ omkostning og effekt. Erfaringer fra Tyskland, Holland, Schweiz, England, Norge og Sverige. København: KORA - Det Nationale Institut for Kommuners og Regioners Analyse og Forskning.

Holst, E. Q. and Toft, O. N. M. (2016). Kritik af ny model for prioritering af medicin. Altinget, [online]. 4. februar 2016. Available at http://www.altinget.dk/artikel/kritik-af-ny-model-for-prioritering-af-medicin [Accessed January 15, 2017].

Kjeldtoft, S. (2016). Regionerne anklages for fejlagtig afvisning af livsforlængende medicin. Information, 30. september 2016, sektion 1, s. 1.

Lynge, L. (2015). Politisk medicinløfte under TV-duel. MedWatch, 1. juni 2015 [online]. Available at: http://medwatch.dk/Sygdom__ Sundhed/article7749776.ece [Accessed January 15, 2017].

Moreira, T. (2012). The Transformation of Contemporary Health Care. New York; London: Routledge.

Nielsen, H. F. (2016a). Patienterne føler sig taget som gidsler. Jyllands-Posten, 6. februar 2016, sektion 1, s. 12.

Nielsen, H. F. (2016b). Regionernes eget prioriteringsråd møder modstand på Christiansborg. Jyllands-Posten, 5. februar 2016, sektion 1, s. 9. 
Nielsen, H. F. (2016c). Regnedrenge får mindre magt. Jyllands-Posten, 7. april 2016, sektion 1, s. 2.

Nord, E. (1999). Cost-value analysis in health care: Making sense out of QALYs. Cambridge: Cambridge University Press.

Pedersen, K. M. (2015). Prioritering i sundhedsvaesenet. Hvorfor er det nødvendigt? København: Munksgaard.

Ritzau. (2016). Læger: Patienter får samlet mere sundhed for pengene. Berlingske [online] $d$. 5. februar 2016. Available at: https://www.b.dk/nationalt/laegerpatienter-faar-samlet-mere-sundhed-for-pengene [Accessed January 15, 2017].

Sjögren, E. and Helgesson, C. F. (2007). The Q(u)ALYfying hand: health economics and medicine in the shaping of Swedish markets for subsidized pharmaceuticals. The Sociological Review, vol. 55(2), pp. 215-240.

Stark, D. (2009). The Sense of Dissonance: Accounts of Worth in Economic Life. New Jersey; Woodstock, Oxfordshire: Princeton University Press.

Sundheds- og Ældreministeriet. 2016. Princippapir om prioritering for sygehuslagemidler af 31. marts 2016. København: Sundheds- og Ældreministeriet.

Toft, O. N. M. (2015). Ubehagelig medicindiskussion presser sig på. Altinget, 11. marts 2015 [online]. Available at: http://www.altinget.dk/sundhed/artikel/ubehageligmedicindiskussion-presser-sig-paa [Accessed January 15, 2017].

Vangkilde, J. and Rasmussen, L. I. (2015). Sygehuse advarer: Dyrt medicinløfte fører til forringelser. Politiken, 1. juni 2015 [online] Available at: http://politiken.dk/indland/politik/folketingsvalg2015/art5578211/Sygehuseadvarer-Dyrt-medicin1\%C3\%B8fte-f\%C3\%B8rer-til-forringelser [Accessed January 15, 2017].

Wadmann, S. and Bang, L. E. (2015). Rationalising prescribing: Evidence, marketing and practice-relevant knowledge. Social Science \& Medicine, vol. 135, pp. 109116.

Weinstein, M. and Stason, W. (1977). Foundations of cost-effectiveness analysis for health and medical practices. New England Journal of Medicine, vol. 296, pp. 716-721.

Winther, J. and Thorup, S. B. (2012a). Forslag om at sætte pris på et menneskeliv. Information 20. februar 2012 [online] Available at: https://www.information.dk/indland/2012/02/forslag-saette-pris-paa-menneskeliv [accessed January 15, 2017].

Winther, J. and Thorup, S. B. (2012b). Hvad må et liv koste? Information 20. februar 2012 [online] Available at: https://www.information.dk/indland/2012/02/maa-livkoste [Accessed January 15, 2017].

Wulff, H. R., Pedersen, S. A. and Rosenberg, R. (2003). Medicinsk Filosofi. København, Munksgaard. 